\title{
The Effects of ECSOTIC Program (Education Information Technology-Based Online System) in Increasing the Knowledge, Attitude, and Practices of Community in Dealing with the COVID-19 Pandemic
}

\author{
R Endro Sulistyono*, Sri Wahyuningsih, Nurul Hayati, Achlish Abdillah, Syaifuddin Kurnianto \\ Nursing Study Program, Faculty of Nursing, University of Jember, Jember, Jawa Timur, Indonesia
}

Submitted: December $9^{\text {th }}$ 2020; Revised: August 17 th $^{\text {2021; }}$ Accepted: August $23^{\text {rd }} 2021$

\begin{tabular}{|c|c|}
\hline Keywords: & Abstract The Covid-19 pandemic has had an impact on society in the fields of \\
\hline Attitude & policy, religion, society, culture, economy, technology, and education. This \\
\hline Behavior & ivity aimed to increase the knowledge, attitude, and behavior of the \\
\hline $\begin{array}{l}\text { Community } \\
\text { strengthening }\end{array}$ & $\begin{array}{l}\text { community regarding the COVID-19 pandemic through education information } \\
\text { technology-based online system. This study was a quasi-experiment with one }\end{array}$ \\
\hline Education & $\begin{array}{l}\text { group pre-test and post-test design. The activity was carried out for four } \\
\text { months on three groups, namely children adolescents, and adults. The planned }\end{array}$ \\
\hline & ut the dangers of Covid-19, increasing reading literacy and \\
\hline $\begin{array}{l}\text { based online } \\
\text { system }\end{array}$ & $\begin{array}{l}\text { wledge through posters, memes, and videos about Covid-19, overcoming } \\
\text { preventing Covid-19, providing entrepreneurial skills during the Covid-19 } \\
\text { demic. The implementation method followed several steps: identifying }\end{array}$ \\
\hline $\begin{array}{l}\text { Health } \\
\text { education }\end{array}$ & $\begin{array}{l}\text { potential and analyzing problems in the community, namely by conducting } \\
\text { FGDs with related parties, program design, library research to reference }\end{array}$ \\
\hline Knowledge & material used during service, making program materials, and implementing them \\
\hline & $\begin{array}{l}\text { online and offline media by visiting the community. The findings showed that } \\
\text { there was an increase in the level of community knowledge, attitude, and } \\
\text { behavior regarding the COVID-19 pandemics. This study found that the } \\
\text { community should be approached in different ways based on their } \\
\text { developmental stage relating to their ability to receive information. }\end{array}$ \\
\hline
\end{tabular}

\section{INTRODUCTION}

The coronavirus or severe acute respiratory syndrome coronavirus 2 (SARS-CoV-2) is a virus that attacks the respiratory system or is commonly known as COVID19. This coronavirus can cause disturbances in the respiratory system, acute pneumonia, or even death. The current COVID-19 outbreak has triggered social stigma and discriminatory behavior against people of certain ethnic backgrounds as well as anyone who is deemed to have had contact with the virus. Due to this pandemic, numerous countries have implemented policies lockdowns. In Indonesia, its government has implemented such a policy, and the most important role in dealing with this outbreak is that of the community itself (Nuryanti, 2020).
The implementation of lockdown and social distancing methods on the one hand can reduce the rate of spread of the virus as experienced by China and South Korea. On the other hand, this policy can also bring consequences that are no less painful. Both methods can hamper the economy in areas where this measure is implemented, especially in Indonesia. Various incidents have shown that the COVID-19 pandemic has spread to the social 'body' of society. It enters, reproduces, and eventually triggers conflicts in society, both horizontally among people and vertically between government and society (Agung, 2020).

The number of Covid-19 patients in East Java Province was in second place with 1114 confirmed positive patients for Covid-19; 177 people had been declared recovered from the Covid-19, and 117 patients

ISSN 2460-9447 (print), ISSN 2541-5883 (online)

${ }^{*}$ Corresponding author: R Endro Sulistyono

Nursing Study Program, Faculty of Nursing, University of Jember, Jl. Kalimantan No.37, Krajan Timur, Sumbersari, Sumbersari, Jember, Jawa Timur 68121, Indonesia

Email: radendro1988@unej.ac.id 
died in September 2020 (Mukaromah, 2020). The number of Covid-19 incidents in the Lumajang area was 24 people; two Covid-19 patients had been declared recovered, and four patients died in 2020 . Lumajang's data for the Jogotrunan area shows that there is only one incidence (one person) of Covid-19.

The increase in the number of COVID-19 sufferers in Lumajang was not accompanied by public compliance with health protocols that must be followed. Jogotrunan Village already had its residents who had been confirmed positive for the Covid-19. The patient and his family underwent independent isolation. The road to the patient's house has been blocked with a red line put by the village authority. The occurrence of the spread of the coronavirus had made all people nervous and did not know what to do in the events like this. Patients and families accept exclusion from the surrounding community. The people of Jogotrunan Village are very diverse; there are health workers (doctors, nurses), lecturers, Islamic religious teachers, but public awareness is still low. There are still many people who did not wear masks, congregated, and did not wash their hands regularly. The results of the assessment in May 2020 were obtained from five residents who were interviewed about COVID-19. Four people said they did not the symptoms of COVID-19 and how it transmits to other people, did not comply with health protocols. Three people did not know that COVID-19 could be dangerous. These findings showed that the community had poor knowledge about the COVID-19 pandemic.

Improving community knowledge and awareness regarding COVID-19 can be done by providing health education for the community. The ECSOTIC program (education information technology-based online system) is a proposed program by this community services team to improve the community's knowledge through technology-based health education. This program reached the community that consisted of three different age groups (children, adolescents, and adults). The problems were identified through focus group discussions at the beginning of the community service. Therefore, this intervention program was deemed appropriate, effective, and based on the community's needs.

Communication among the residents had been made through a social media platform (WhatsApp group), but there had been little or useful information about COVID-19. The community is very obedient to the leadership (head of the village, head of the RW). The community's attitude that is obeying their community leaders is a potential capital to be utilized by the community service team to deliver health information about COVID-19. Each target group was treated with a different approach. The children group tended to prefer a kind of health education that was accompanied by the play therapy method. The adolescent group was approached by a technology use method, and the adult group preferred to be approached by involving their leadership. The contents of ECSOTIC program were developed based on the community's needs for information relating to COVID19.

The ECSOTIC program consisted of health education in various topics. The topics were related to health protocols to prevent COVID-19 spreads in the community (hand sanitizing using hand sanitizers, keeping a distance from others for at least 1 meter, and avoiding crowd), information about COVID-19 (definition, causes of COVID-19, symptoms, and COVID-19 treatments), and efforts to remove the stigma attached to COVID-19 patients (Abdillah, 2020). The elderly and people with underlying chronic diseases usually have a poor prognosis whereas cases with relatively mild symptoms often occur in children (Safrizal et al., 2020). By considering this fact, there must be a mutual agreement among the community members not to criticize the patients, but together they should have and be able to achieve a common goal, namely fighting COVID-19 (Nurlita, 2020). Based on the background, this study aimed to improve the knowledge, attitude, and behavior of the community in Jogotrunan Village regarding COVID-19 through ECSOTIC program (education information technology-based online system).

\section{METHOD}

This study was a quasi-experiment using the pre-posttest approach. This community service was conducted through four stages and held from August to September 2020. The activities conducted by involving the community target were in the forms of training and counseling with the following steps:

1. Preparation stage

2. Activity planning stage

3. The activity implementation stage

4. Evaluation stage

Table 1. Participant characteristics

\begin{tabular}{llll}
\hline Participants & n & $\%$ \\
\hline Sex & & 9 & 53 \\
& Man & 8 & 47 \\
& Woman & & \\
Job & & 5 & 29 \\
& Sub-district government staff & 5 & 29 \\
& Sub-district citizens & 3 & 18 \\
& Public Health Center staff & 2 & 12 \\
$\quad$ PKK members & 2 & 12 \\
$\quad$ Babinsa */babinkamtibmas * & \\
* a village supervisory non-commissioned officer \\
* a member of the Indonesian National Police tasked with \\
fostering public security and order
\end{tabular}

In the preparation stage, an analysis of the situation and problems of partners was carried out to 
understand what problems were faced by the target community regarding the COVID-19 pandemic. During this stage, these problems were elicited from the community leaders (Table 1) during a focus group discussion. The community leaders that participated in this stage were 17 people who had various occupational backgrounds. The results of the focus group discussion were then mapped according to Leininger's sunrise model (policy, religion, social, culture, economy, technology, and education).

In the planning stage, the focused group discussions were held by the community service team, and the community leaders were invited; together they tried to find solutions to the problems. At this stage, we identified the problems that were faced by the target community and discussed plans to solve these problems (Table 2). At the implementation stage, health education about COVID-19 was provided once in two weeks during the three months. This health education was delivered following the characteristics of the three groups: children group (7-12 years old), adolescent group (13-19 years old), and adult group ( $>20$ years old). The participants were chosen through random sampling. This community service project was conducted from September to November 2020. The health education was provided through varied methods and was delivered via the internet- online (Table 3 ). The total number of the respondent was 60 participants (20 children, 20 adolescents, and 20 adults). The pre-test was carried out before the health education was provided, and the post-test was carried out one week after the last intervention measure was implemented. In the pre-test and post-test, the participants were asked to fill out questionnaires about COVID-19. Each group also received special educational materials; the children were educated using educational games that involved hot potatoes and a flash player. The adolescents were taught how to create creative content using Photoshop, Corel, and adobe premiere. The adult group was facilitated and encouraged to reactivate their Qur'an recitation and family welfare empowerment program (PKK). They were taught to make products from moringa, which is one of the mainstays of Lumajang people's diet, and it is nutritious as it is high in vitamin D.
The concept of the ECSOTIC Program was that every person entering the village must be presented with information about COVID-19. People from outside could ask information about COVID-19 to any community members, and they would be able to answer the visitors correctly. The village's walls were decorated with educative murals, moringa was planted along the village's roads; in public areas, banners were put up, and handwashing facilities were installed.

\section{RESULT AND DISCUSSION}

The participants' demographic characteristics can be seen in Table 4. Most of the participants were female (53.3\%), and their age mean was 21.78 years old. During the implementation of the community service, approaching the participants was difficult because the team was considered outsiders. After involving the community leaders to approach the target community in Jogotrunan village, it was easy to recruit participants.

The different approaches to providing health education to the three target groups seemed to be effective in improving their willingness to participate. This showed that the choice of methods in delivering intervention programs must consider the developmental stage of target individuals.

Table 5 shows the differences in knowledge, attitudes, and practices of the community in response to COVID-19 before and after the community services program (ECSOTIC) was conducted. Before the ECSOTIC program was delivered, fifteen (25\%) respondents stated that they did not know that the main clinical symptoms of COVID-19; others (28.4\%) did not know that COVID-19 can be cured; Seventy percent of them believed that persons with COVID-19 cannot spread the virus when no symptom is present; some (36.7\%) believed that children and adolescents did not need to obey the health protocols prescribed by the government; some participants $(16.7 \%)$ did not believe that COVID-19 could be controlled and mitigated; more than half of the participants $(58.3 \%)$ had recently visited a crowded place, $33.3 \%$ of them and did not wear a mask when leaving their homes.

Table 2. Topics and results of focus group discussion

\begin{tabular}{|c|c|c|c|c|}
\hline Group & & problems & cause & Solution plan \\
\hline \multirow[t]{4}{*}{ Adult } & & Difficulties in selling goods & Limited buyers due to the pandemic & $\begin{array}{l}\text { Online selling (social media, } \\
\text { website, etc.) }\end{array}$ \\
\hline & & Disobedience to health protocols & Limited access in health services & Health education \\
\hline & & during the pandemic & Unwillingness to obey health protocols & \\
\hline & & & Feeling less comtortable when wearıng a mask & \\
\hline \multirow{6}{*}{$\begin{array}{l}\text { Children } \\
\text { Teenager }\end{array}$} & and & Disobedience to health protocols & Little information & Health education \\
\hline & & & Lack of awareness & \\
\hline & & & Lack of parents' awareness & \\
\hline & & & Lack of knowledge & \\
\hline & & Limited activities & Schooling from home & Health education \\
\hline & & & Lack of parents' engagement & \\
\hline
\end{tabular}


Table 3. Community service activities

\begin{tabular}{|c|c|c|}
\hline \multicolumn{3}{|c|}{ The First Week } \\
\hline Video & Infographic & Meme \\
\hline Introduction to COVID-19 & Where is covid? & What if covid is big? \\
\hline Tausyiah text & Animation & Poster \\
\hline $\begin{array}{c}\text { Infectious disease from religion point of } \\
\text { view }\end{array}$ & Virus transmission and body responses & Am I positive? \\
\hline Booklet & Sound & Tiktok \\
\hline Covid prevention & Community mutual help & PHBS in Family \\
\hline $\begin{array}{c}\text { Flyer } \\
\text { Covid examination } \\
\text { Rapid and swab test }\end{array}$ & Can Covid-19 be cured? & $\begin{array}{l}\text { Flash animation } \\
\text { Facts and myths about covid }\end{array}$ \\
\hline $\begin{array}{c}\text { Poster } \\
\text { Covid prevention }\end{array}$ & $\begin{array}{l}\text { Photoshoot } \\
\text { World innovation } \\
\text { to fight Covid-19 }\end{array}$ & $\begin{array}{c}\text { Video } \\
\text { Self-isolation }\end{array}$ \\
\hline $\begin{array}{c}\text { Text content } \\
\text { Obeying the leader }\end{array}$ & $\begin{array}{c}\text { Slideshow } \\
\text { Government recommendations }\end{array}$ & $\begin{array}{c}\text { Quote } \\
\text { Reinforcing mutually }\end{array}$ \\
\hline $\begin{array}{l}\text { Flow chart } \\
\text { The differences among diseases that cause } \\
\text { coughs (TB, Bronchitis, covid, ARI, etc.) }\end{array}$ & $\begin{array}{c}\text { Tausyiah } \\
\text { Fighting during covid }\end{array}$ & $\begin{array}{c}\text { Poster } \\
\text { Be always aware }\end{array}$ \\
\hline \multicolumn{3}{|c|}{ The Second and Third week: Introduction and Training } \\
\hline Children group & Quizzes, educational games with Moodle and flash & \multirow{3}{*}{$\begin{array}{l}\text { Covid-19 education topics adjusted to } \\
\text { online product guidance and } \\
\text { trends/issues }\end{array}$} \\
\hline Teenager group & $\begin{array}{l}\text { - Zoom: introduction and utilization } \\
\text { - FGD on the concept of training } \\
\text { - Look for branding concepts from the youth } \\
\text { perspective }\end{array}$ & \\
\hline Adult group & $\begin{array}{l}\text { - Zoom: introductory and utilization } \\
\text { - Reactivation of Qur'an recitation and PKK using } \\
\text { zoom meeting } \\
\text { - FGD on training to make cakes made from moringa } \\
\text { - FGD on the ECSOTIC urban village branding } \\
\text { concept }\end{array}$ & \\
\hline \multicolumn{3}{|l|}{ Second month: application } \\
\hline Children group & Learning activities with nurses & \multirow{3}{*}{$\begin{array}{l}\text { Covid education topics adjusted to online } \\
\text { product guidance and trends/issues }\end{array}$} \\
\hline Teenager group & $\begin{array}{l}\text { Create videos, posters, booklets, tiktok, and other } \\
\text { media }\end{array}$ & \\
\hline Adult group & $\begin{array}{l}\text { Making cake products } \\
\text { Moringa planting } \\
\text { Creating a Covid-19 park }\end{array}$ & \\
\hline \multicolumn{3}{|l|}{ Third month: Testing and marketing } \\
\hline Teenager group & $\begin{array}{l}\text { Disseminating covid information using videos, } \\
\text { posters, booklets, tiktok, and other media }\end{array}$ & \multirow[t]{2}{*}{$\begin{array}{l}\text { Covid education topics adjusted to online } \\
\text { product guidance and trends/issues }\end{array}$} \\
\hline Adult group & $\begin{array}{l}\text { Online marketing of cake products (packing, } \\
\text { promoting, and selling) } \\
\text { Moringa planting } \\
\text { Creating a Covid-19 park }\end{array}$ & \\
\hline
\end{tabular}

Table 4. Demographic characteristics of participants

\begin{tabular}{lll}
\hline \multicolumn{1}{c}{ Variables } & $\mathrm{n}$ & $\%$ \\
\hline Sex $\quad$ Male & 28 & 46.7 \\
$\quad$ Female & 32 & 53.3 \\
Age (Mean = 21.78) & & \\
$7-12$ & 20 & 33.3 \\
$13-19$ & 20 & 33.3 \\
$>20$ & 20 & 33.4 \\
\hline
\end{tabular}

After the intervention, $100 \%$ of respondents stated that they knew the main clinical symptoms of COVID19. Eighty-five percent of them knew that COVID-19 could be cured. Only some of the participants $(8.3 \%)$ still believed that persons with COVID-19 cannot spread the virus when no symptom is present; $13.4 \%$ of them believed that children and adolescents didn't need to obey the health protocol prescribed by the government. Ninety percent of the participants believed that COVID-19 could finally be controlled. Forty percent of them had visited a crowded place recently, and almost all (91.7\%) wore face masks when they left their homes.
Most of the activities of this community service program were carried out in person and through social media platforms Instagram and YouTube. Consequently, the implementation time became more flexible, and this was following the health protocol for preventing further transmission of SARS-CoV-2. Figure 1 is a poster showing the prevention of COVID19, and Figure 2 is a meme about cuting off COVIS-19 transmission. These media were shared via social media WhatsApp and Instagram. The participants were trained and facilitated to create such educational posters, so that they can increase their knowledge about COVID-19, their reading literacy, and their awareness of the disease. Interesting and informative educational media can attract the public to read and increase their understanding of COVID-19. During this community service, the use of social media attracted the children and adolescent groups, who had been using social media and technology every day. 
Table 5. The differences in knowledge, attitudes, and practices of the target community in response to COVID-19 before and after the community services program

\begin{tabular}{|c|c|c|c|c|c|c|}
\hline \multirow[t]{2}{*}{ Questions } & \multicolumn{3}{|c|}{ Before } & \multicolumn{3}{|c|}{ After } \\
\hline & Yes & No & $\begin{array}{l}\text { Do not } \\
\text { Know }\end{array}$ & Yes & No & $\begin{array}{l}\text { Do not } \\
\text { Know }\end{array}$ \\
\hline \multicolumn{7}{|l|}{ Knowledge } \\
\hline $\begin{array}{l}\text { The main clinical symptoms of COVID-19 are fever, dry } \\
\text { cough, and muscle pain. }\end{array}$ & $\begin{array}{c}40 \\
(66.7 \%)\end{array}$ & $\begin{array}{c}5 \\
(8.3 \%)\end{array}$ & $\begin{array}{c}15 \\
(25 \%)\end{array}$ & $60(100 \%)$ & 0 & 0 \\
\hline Currently, there is no effective cure for COVID- 19 . & $\begin{array}{c}32 \\
(53.3 \%)\end{array}$ & $\begin{array}{c}11 \\
(18.3 \%)\end{array}$ & $\begin{array}{c}17 \\
(28.4 \%)\end{array}$ & $\begin{array}{c}51 \\
(85 \%)\end{array}$ & $\begin{array}{c}6 \\
(10 \%)\end{array}$ & $\begin{array}{c}3 \\
(5 \%)\end{array}$ \\
\hline $\begin{array}{l}\text { Persons with COVID-19 cannot spread the virus when no } \\
\text { symptom is present. }\end{array}$ & $\begin{array}{c}42 \\
(70 \%)\end{array}$ & $\begin{array}{c}4 \\
(6.7 \%)\end{array}$ & $\begin{array}{c}14 \\
(23.3 \%)\end{array}$ & $\begin{array}{c}5 \\
(8.3 \%)\end{array}$ & $55(91.7 \%)$ & 0 \\
\hline The COVID-19 viruses spread via respiratory droplets & $\begin{array}{c}43 \\
(71.7 \%)\end{array}$ & $\begin{array}{c}5 \\
(8.3 \%)\end{array}$ & $\begin{array}{c}12 \\
(20 \%)\end{array}$ & $\begin{array}{c}57 \\
(95 \%)\end{array}$ & $\begin{array}{c}3 \\
(5 \%)\end{array}$ & 0 \\
\hline $\begin{array}{l}\text { Children and adolescent are not necessary to obey the health } \\
\text { protocol prescribed by the government }\end{array}$ & $\begin{array}{c}22 \\
(36.7 \%)\end{array}$ & $\begin{array}{c}21 \\
(35 \%)\end{array}$ & $\begin{array}{c}17 \\
(28.3 \%)\end{array}$ & $\begin{array}{c}8 \\
(13.4 \%)\end{array}$ & $\begin{array}{c}52 \\
(82.6 \%)\end{array}$ & 0 \\
\hline \multicolumn{7}{|l|}{ Attitude: } \\
\hline I agree that COVID-19 could be controlled finally. & $\begin{array}{c}50 \\
(83.3 \%)\end{array}$ & $\begin{array}{c}4 \\
(6.7 \%)\end{array}$ & $\begin{array}{c}6 \\
(10 \%)\end{array}$ & $\begin{array}{c}54 \\
(90 \%)\end{array}$ & 0 & $\begin{array}{c}6 \\
(10 \%)\end{array}$ \\
\hline I agree that COVID-19 threatens my surrounding community & $\begin{array}{c}32 \\
(53.3 \%)\end{array}$ & $\begin{array}{c}21 \\
(35 \%)\end{array}$ & $\begin{array}{c}7 \\
(11.7 \%)\end{array}$ & $\begin{array}{c}49 \\
(81.7 \%)\end{array}$ & $\begin{array}{c}11 \\
(18.3 \%)\end{array}$ & 0 \\
\hline $\begin{array}{l}\text { I agree that obeying health protocol prescribed by the } \\
\text { government can control the COVID-19 pandemic. }\end{array}$ & $\begin{array}{c}35 \\
(58.3 \%) \\
\end{array}$ & $\begin{array}{c}19 \\
(31.7 \%)\end{array}$ & $\begin{array}{c}6 \\
(10 \%) \\
\end{array}$ & $\begin{array}{c}57 \\
(95 \%) \\
\end{array}$ & $\begin{array}{c}3 \\
(5 \%) \\
\end{array}$ & 0 \\
\hline \multicolumn{7}{|l|}{ Practice: } \\
\hline I went to a crowded place recently. & $\begin{array}{c}35 \\
(58.3 \%)\end{array}$ & $\begin{array}{c}25 \\
(41.7 \%)\end{array}$ & 0 & $\begin{array}{c}24 \\
(40 \%)\end{array}$ & $\begin{array}{c}36 \\
(60 \%)\end{array}$ & 0 \\
\hline I wear mask when leaving my house & $\begin{array}{c}32 \\
(53.3 \%)\end{array}$ & $\begin{array}{c}20 \\
(33.3 \%)\end{array}$ & $\begin{array}{c}8 \\
(13.4 \%)\end{array}$ & $\begin{array}{l}55 \\
(91.7 \%)\end{array}$ & $\begin{array}{l}5 \\
(8.3 \%)\end{array}$ & 0 \\
\hline I often wash my hand when travelling to other places. & $\begin{array}{c}31 \\
(51.7 \%)\end{array}$ & $\begin{array}{c}23 \\
(38.3)\end{array}$ & $\begin{array}{c}6 \\
(10 \%) \\
\end{array}$ & $\begin{array}{c}49 \\
(81.7 \%)\end{array}$ & $\begin{array}{c}11 \\
(18.3 \%)\end{array}$ & 0 \\
\hline
\end{tabular}

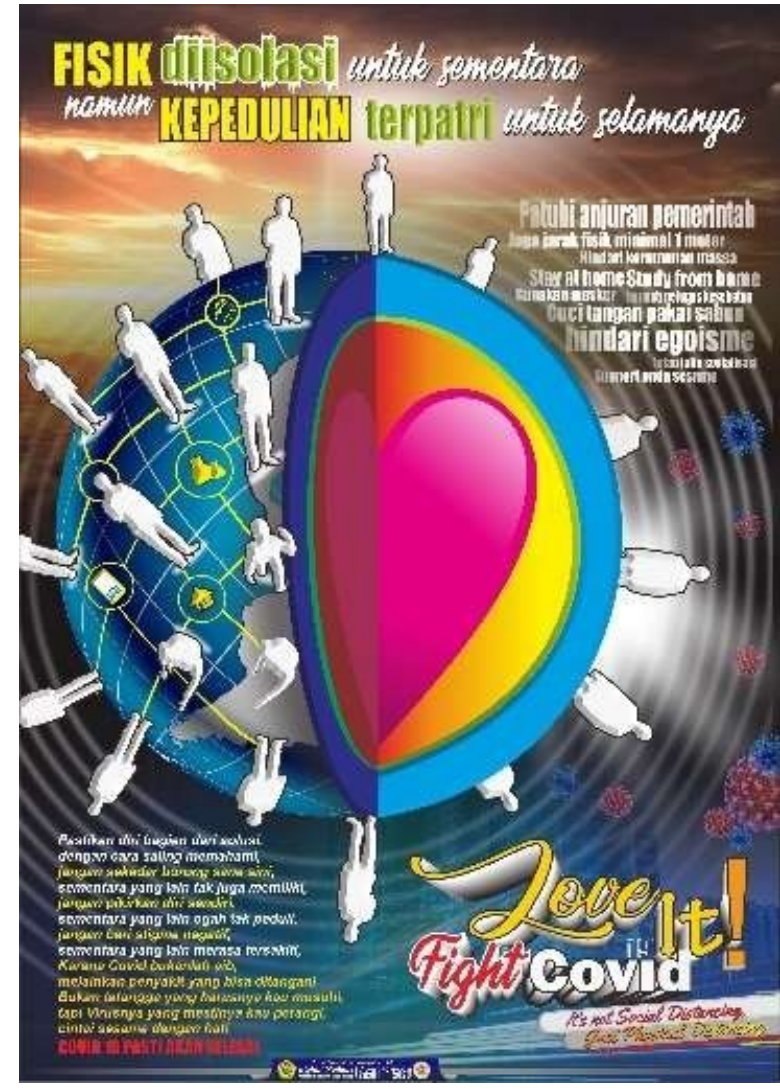

Figure 1. COVID-19 prevention poster transmission

Figure 3 explains about different types of face masks worn to prevent COVID-19 transmission. Wearing such masks is a critical action to prevent the transmission of COVID-19. Various studies have proven the effectiveness of face masks in preventing respiratory infections; N95 face masks and surgical masks have an effectiveness of above $90 \%$.

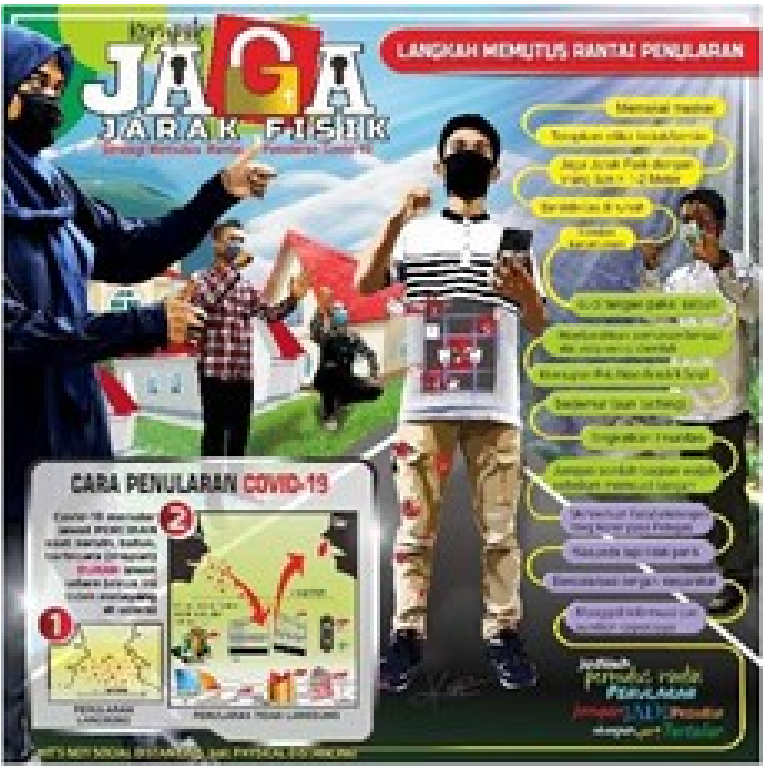

Figure 2. Meme about cutting off COVID

To maintain the availability of face masks, the general public is strongly recommended to wear cloth face masks. The recommended type is 3 -layer cloth face masks. Wearing 1-layer cloth masks such as scuba and buff are strongly discouraged because they do not have sufficient protection against aerosol particles of SARS$\mathrm{CoV} 2$. The use of face masks by children must be under supervision as various studies have reported there are potential respiratory problems in children when they are wearing face masks for a long period. Face masks can still be worn by children under certain conditions, and it must be ensured that they are under the supervision of a parent or an adult. 


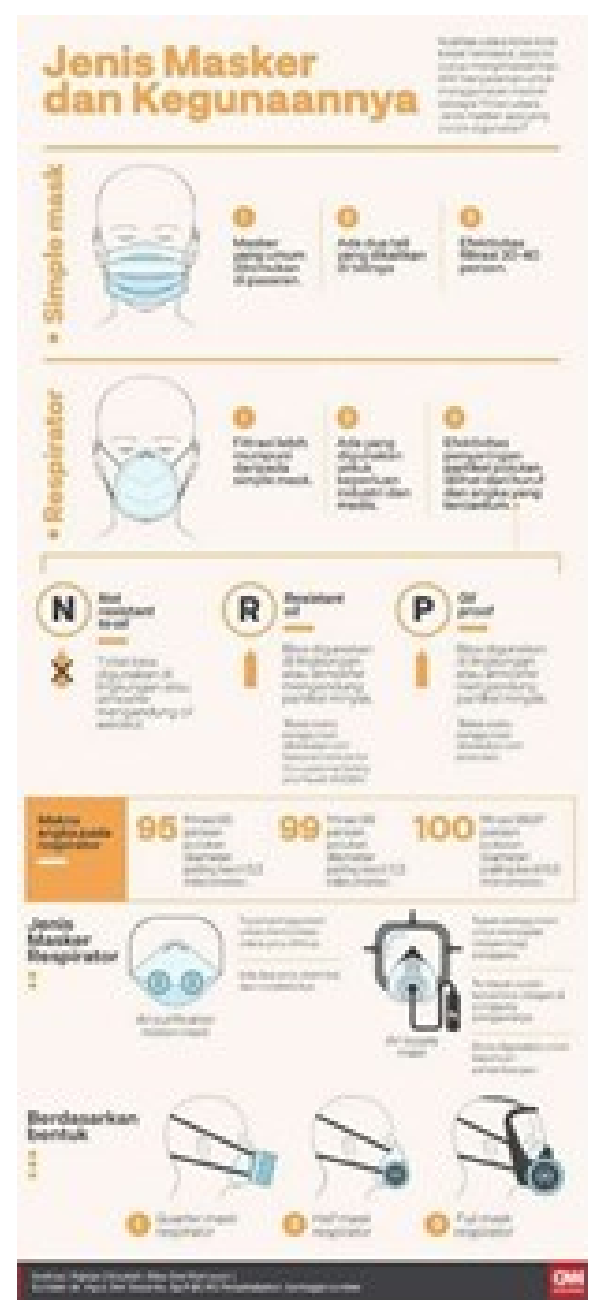

Figure 3. Face mask infographic

Figure 4 is a photograph showing the handing over of moringa tree seeds to the target community and their planting. One of the benefits that can be enjoyed from moringa trees is their leaves (Kouevi, 2013). The findings of the research done by Fuglie (2001) showed that moringa leaves contain various beneficial nutrients. The most superior content in these leaves is protein, vitamin A ( $\beta$-carotene), and high iron, so that they are good for consumption and can meet the human body's nutritional needs, especially among vulnerable groups (Madukwe et al., 2013). In addition, moringa leaves also contain various kinds of amino acids which are rarely found in other vegetables (Kasolo et al.,
2010). Another benefit of moringa leaves is that they can improve the nutritional status of malnourished children. Research conducted by (Srikanth et al., 2014) revealed that moringa leaves can overcome the problem of malnutrition in various countries by adding it to the daily diet of children.

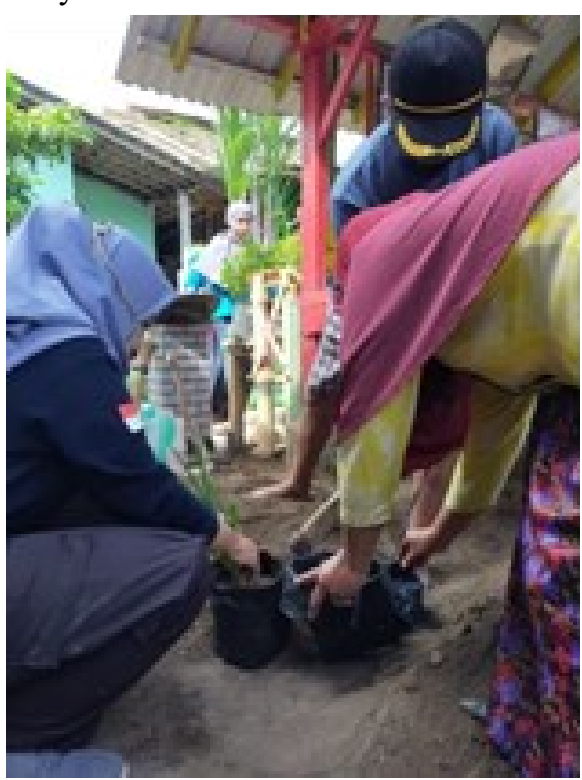

Figure 4. Planting sengon for the community

Figure 5 is a picture of the campaign for preventing the spread of COVID-19 through the distribution of face masks and hand sanitizers accompanied by providing education on how to wear face masks correctly, how to wash hands, and the need for physical distancing. Through this community service program, the target community not only learned how to wear face masks correctly, but they were also encouraged to be disciplined in wearing these masks correctly daily because it is an effective preventive action against COVID-19. Through this activity, the community had become more aware of the importance of protecting themselves from infectious diseases, especially Covid-19. Before this community service program, some participants did not wear a mask because they did not know its importance and the price of face masks was still expensive, and they were difficult to obtain. Therefore, distributing face masks

Tabel 4. Videos and their links used during the community service program

\begin{tabular}{|c|c|}
\hline Video Tittle & Link \\
\hline $\begin{array}{l}\text { Short movie with tittle "Apa itu New Normal?"/ } \\
\text { what is new normal? }\end{array}$ & $\begin{array}{l}\text { Youtube channel "Jogotrunan Ecsotik" at link: } \\
\text { https://www.youtube.com/watch?v=BJOhv2KD3UQ }\end{array}$ \\
\hline $\begin{array}{l}\text { Video with tittle "Apa itu Covid-19"? / "what is } \\
\text { COVID-19"? }\end{array}$ & $\begin{array}{l}\text { Youtube channel "Jogotrunan Ecsotik" at link: } \\
\text { https://www.youtube.com/watch?v=P0Z-hjley-o }\end{array}$ \\
\hline Video with tittle "Mengaji 1"/"Recite 1" & $\begin{array}{l}\text { Youtube channel "Jogotrunan Ecsotik" at link: } \\
\text { https://www.youtube.com/watch?v=NIPQo gqueM }\end{array}$ \\
\hline Video with tittle "Mengaji 2"/"Recite 2" & $\begin{array}{l}\text { Youtube channel "Jogotrunan Ecsotik" at link: } \\
\text { https://www.youtube.com/watch?v=3avualJ2jFg }\end{array}$ \\
\hline Video with tittle "Mengaji 3"/"Recite 3" & $\begin{array}{l}\text { Youtube channel "Jogotrunan Ecsotik" at link: } \\
\text { https://www.youtube.com/watch?v=4xjwvB6rlaE }\end{array}$ \\
\hline $\begin{array}{l}\text { Video with tittle } \\
\text { "Covid itu begini lohh..."/" Covid is....." }\end{array}$ & $\begin{array}{l}\text { Youtube channel "Jogotrunan Ecsotik" at link: } \\
\text { https://www.youtube.com/watch?v=RyAURgE0b1c }\end{array}$ \\
\hline $\begin{array}{l}\text { Tiktok with tittle "10 PHBS Tatanan Rumahm } \\
\text { Tangga"/"10 Health behavior in family" }\end{array}$ & $\begin{array}{l}\text { Youtube channel "Jogotrunan Ecsotik" at link: } \\
\text { https://youtu.be/ygm } 43 \text { sLf2E }\end{array}$ \\
\hline
\end{tabular}


and hand sanitizers to the target community was aimed to benefit them and help them to follow the health protocol during this pandemic.

The dissemination of educational materials was the core activity of this community service project. Participants were asked to read various educational media that had been prepared by the community service team and watch short videos related to what COvid-19 is, how it is transmitted, and how to prevent its transmission. Both in the children and adolescent groups, assistance was also provided for their parents. This was done to educate parents in maintaining and implementing the health protocol for their children, especially during this COVID-19 pandemic.

This study showed that technology-based health education can improve knowledge, promote positive attitudes, and encourage good practices in the target community in responding to COVID-19. A previous study found that digital education is at least as effective as conventional education, and surely it is a good solution for the absence of learning (Brusamento et al., 2019). Online health education in difficult situations such as during the COVID-19 can be a substitute for the traditional health education usually taking place in a classroom. Online health education also has the advantage that the materials can be accessed anytime by the participants.

The work procedures to support the realization of the methods offered to Lumajang Regency encouraged the community and religious leaders to help implement these methods to remove the stigma attached to people suffering from COVID-19. Each village has a small community group such as Karang Taruna (Youth Association), Remas (Mosque Youth Association), PKK (Family Welfare Empowerment), and so on. The educational media created by the community service team were distributed through the RW (Community Unit) head and then to smaller groups and the entire village community. As a result, the health worker team, community leaders, religious leaders, and the entire target community were able to work together in fighting the COVID-19 pandemic. The community could also understand the spread and handling of COVID-19, and they could have positive attitudes to avoid stigmatizing those who were infected with SARS-CoV-2. In addition, after receiving the COVID-19 education the target community would be more careful in accessing information so that they could identify false news.

It is hoped that after this community service, the D3 Nursing Study Program of Faculty of Nursing of University of Jember, Lumajang Campus, will be able to provide continuous nursing care in the target village and always make improvements in carrying out activities related to its students' learning process in the assisted village. These activities will always be jointly monitored and evaluated. From these activities, a concept paper containing recommendations will be submitted to policymakers (health service providers), DPRD (a local house of representatives), sub-district heads, the regent, so that a joint commitment can be formed along with its legal supports, supporting policies, funding, other necessary supports.

\section{CONCLUSION}

Through this community service program, the knowledge and understanding of the community regarding COVID-19 and how to prevent are believed to have increased. Every stage of this community service program could be organized successfully and smoothly thanks to the supports given by various parties.

\section{ACKNOWLEDGMENT}

We would like to thank all participants, all government officials in Jogotrunan, head of the village, head of the citizens Association/RW, the cadres, and Universitas Jember for allowing the team to carry out this community engagement project.

\section{REFERENCES}

Abd-Elsayed A, Karri J. Utility of Substandard Face Mask Options for Health Care Workers During the COVID-19 Pandemic. Anesth Analg. 2020. doi: 10.1213/ ANE.0000000000004841.

Abdillah, L. A. (2020). Stigma Terhadap Orang Positif COVID-19. eprints. Binadarma.

American Academy of Pediatrics. Masks and children during https://services.aap.org/en/pages/2019. novelcoronavirus-covid-19-infections/masksand children-duringcovid-19/ Accessed 9 September 2020

Agung, I. M. (2020). Memahami Pandemi Covid-19 Dalam Perspektif Psikologi Sosial. Psikobuletin. https://doi.org/http://dx.doi.org/10.24014/pib.v1 i2 .9616

Brusamento, S., Kyaw, B. M., Whiting, P., Li, L., \& Car, L. T. (2019). Digital Health Professions Education in the Field of Pediatrics: Systematic Review and Meta-Analysis by the Digital Health Education Collaboration. J Med Internet Res, 21(9). https://doi.org/10.2196/14231

Fuglie, L. J. (2001). Combating malnutrition with Moringa. In The miracle tree: the multiple attributes of Moringa (pp. 117-136). CTA Publication.

Kasolo, J. N., Bimenya, G. S., Ojok, L., Ochieng, J., \& Ogwal-Okeng, J. W. (2010). Phytochemicals anduses of Moringa oleiferaleavesin Ugandan rural communities. Journal of Medicinal Plants Research, https://doi.org/10.5897/JMPR10.492

Kouevi, K. K. (2013). A study on Moringa oleifera leaves as a supplement to West African weaning foods. Humburg University of Applied Sciences.

Madukwe, E. U., Ezeugwu, J. ., \& Eme, P. E. (2013). Nutrient Composition and Sensory Evaluation of 
Dry Moringa Oleifera Aqueous Extract. International Journal of Basic \& Applied Sciences.

http://www.ijens.org/Vol_13_I_03/1312011303-7474-IJBAS-IJENS.pdf

Mukaromah, V. F. (2020, June 23). 10 Provinsi dengan Jumlah Kasus Covid-19 Tertinggi, Jatim Mulai Dekati DKI. Kompas. https://www.kompas.com/tren/read/2020/06/23/ 184500765/10-provinsi-dengan-jumlah-kasuscovid-19-tertinggi-jatim-mulai-dekati-dki

Nurlita, A. R. (2020). PENTINGNYA PERWUJUDAN BELA NEGARA DI TENGAH KASUS COVID-19 (The Importance of The Embodiment of Defending the Country in The Middle of The Covid-19 Case). SSRN. https://doi.org/http://dx.doi.org/10.2139/ssrn.35 75844

Nuryanti, S. (2020). Peran Masyarakat untuk Bela Negara dalam Menghadapi Covid-19 (The Role of Society for Defending the Country in Facing COVID-19). SSRN. https://doi.org/http://dx.doi.org/10.2139/ssrn.35 75583

Safrizal, Z., Putra, D. I., Sofyan, S., \& Bimo. (2020). Pedoman Manajemen bagi Pemerintah daerah dalam Penanganan COVID-19 dan Dampaknya. Kementerian Dalam Negeri Republik Indonesia.

Srikanth, V., Mangala, S., \& Subrahmanyam, G. (2014). Improvement of Protein Energy Malnutrition by Nutritional Intervention with Moringa Oleifera among Anganwadi Children in Rural Area in Bangalore, India. International Journal of Scientifi c Study, 2(1). http://www.ijsssn.com/uploads/2/0/1/5/20153321/ijss_apr08.pdf 